Zeszyty Naukowe Szkoły Głównej Gospodarstwa Wiejskiego

Ekonomika i Organizacja Gospodarki Żywnościowej nr 118, 2017: 95-109

DOI 10.22630/EIOGZ.2017.118.19

Robert Nowacki, Katarzyna Wasilik

Zakład Rynku Usług

Instytut Badań Rynku, Konsumpcji i Koniunktur w Warszawie

\title{
Znajomość i zaufanie wobec certyfikatów zrównoważonej konsumpcji a idea społecznej odpowiedzialności przedsiębiorstw w perspektywie młodych konsumentów
}

\section{Wstęp}

Zainteresowanie społeczną odpowiedzialnością przedsiębiorstw związane jest z przemianami zachodzącymi na współczesnych rynkach. Jedną z nich jest wzrost świadomości i ewolucja wymagań nabywców w zakresie użyteczności dóbr i usług służących zaspokajaniu coraz bardziej zróżnicowanych potrzeb. Przedsiębiorstwa zmuszone są do poszukiwania nowych dróg sprostania tym oczekiwaniom [Nowacki i Wasilik 2017]. Zachowania konsumentów stanowią bowiem podstawę wszelkich działań podejmowanych przez organizacje [Luo i Bhattacharya 2006] starające się sprostać presji wywieranej w zakresie pożądanych produktów [Wilburn i Wilburn 2014], a także odpowiedzialności ekonomicznej, prawnej, etycznej i filantropii [Griseri i Seppala 2010].

Szczególnie widoczne jest to w segmencie młodych konsumentów (przed 40. rokiem życia), co wynika $z$ ich większej otwartości na zjawiska zachodzące we współczesnym świecie, w tym w konsumpcji. Nie w pełni obciążeni jeszcze obowiązkami dorosłego życia i przywiązaniem do określonych wzorców postępowania, wrażliwi na propagowane w środkach masowego przekazu idee stają się kreatorami nowych trendów, wśród których znaleźć mogą się również działania prospołeczne [OMG! Czyli jak mówić..., 2014]. Żyjąc aktywnie, wykazują większe zainteresowanie jakością życia, a tym samym jakością konsumowanych produktów i usług [Słaby 1990, Bergh i Behrer 2012]. Ich mobilność i otwartość na nowoczesne technologie informacyjne sprzyja ciagłemu poszukiwaniu informacji o składzie produktów, sposobie ich wytwarzania, konsekwencjach 
stosowania dóbr materialnych i korzystania z usług, co wpływa na kształtowanie zjawiska tzw. konsumpcji etycznej [Humphery 2011].

Wychodząca naprzeciw tym trendom społeczna odpowiedzialność przedsiębiorstw znajduje swój wyraz między innymi w podejmowaniu działań wpisujących się w zrównoważoną produkcję. Z punktu widzenia oddziaływania na konsumentów kluczowe znaczenie ma w tym kontekście właściwe propagowanie tych działań związane z wykorzystywaniem odpowiednich certyfikatów. Na tym tle pojawia się pytanie o relacje między świadomością konsumentów w zakresie społecznej odpowiedzialności przedsiębiorstw a postrzeganiem takich działań.

Celem artykułu jest identyfikacja zależności między deklarowaną znajomością i zainteresowaniem działaniami z zakresu społecznej odpowiedzialności przedsiębiorstw wśród młodych konsumentów a znajomością i zaufaniem wobec znaków i certyfikatów potwierdzających zrównoważoną produkcję. Dla potrzeb realizacji powyższego celu autorzy analizują wyniki badań przeprowadzonych metodą sondażu diagnostycznego na próbie 963 młodych konsumentów w 2015 roku.

\section{Idea społecznej odpowiedzialności a jej implikacje dla zachowań konsumentów}

Społeczna odpowiedzialność biznesu (ang. corporate social responsibility - CSR) definiowana jest jako koncepcja, wedle której ,przedsiębiorstwa dobrowolnie uwzględniają aspekty społeczne i ekologiczne w swoich działaniach handlowych oraz w kontaktach ze swoimi interesariuszami" [CEC 2001]. Zgodnie z idącą dalej w kierunku społecznych zobowiązań przedsiębiorstw definicją, społeczna odpowiedzialność jest „,zobowiązaniem biznesu do przyczyniania się do zrównoważonego rozwoju przy współpracy zatrudnionych, ich rodzin, lokalnej społeczności oraz całego społeczeństwa, zmierzającym do poprawy jakości życia, co służy zarówno biznesowi, jak i rozwojowi społecznemu" [World Bank 2005]. W różnych definicjach zwraca się uwagę na pięć kluczowych elementów: obowiązek wykraczania poza produkcję dóbr i usług z zyskiem, obowiązek pomocy w rozwiązywaniu różnych problemów społecznych, szeroki krąg interesariuszy obejmujący nie tylko akcjonariuszy, skutki działalności wykraczające poza transakcje rynkowe oraz powinność szerzenia wartości przekraczających ramy ekonomiczne [Buchholz 1991].

Budowanie strategii działania przedsiębiorstwa odpowiedzialnego społecznie wymusza uwzględnienie na zasadzie dobrowolności interesów społecznych, ochrony środowiska [Carroll 1991] oraz kształtowania odpowiednich relacji z różnymi grupami interesariuszy [Freeman 1984, Freeman i Evan 1990]. 
W aspekcie zachowań konsumentów należy zauważyć, że ich społeczne oczekiwania i zachowania wobec biznesu są siłą sprawczą wymuszającą na przedsiębiorstwach prospołeczne działania [Czubała 2011]. Z wielu badań wynika, że głównymi motywatorami i korzyściami tych działań są przed wszystkim chęć zdobycia zaufania, poprawa i budowa wizerunku organizacji, przychylność inwestorów i instytucji finansowych, osiagganie przewagi konkurencyjnej na rynku oraz wzrost wartości przedsiębiorstwa [Chahal i Sharma, 2006, Economist Intelligence Unit 2009, Witek 2011, Zielińska 2014, Drapińska 2015]. Należy jednak pamiętać, aby nie skupiać się nadmiernie na idei społecznej odpowiedzialności, gdyż skutki tego niekoniecznie będą pozytywne zarówno dla przedsiębiorstw, jak i społeczeństwa [Levitt 1958].

Coraz lepiej poinformowani i bardziej świadomi swych praw konsumenci maja jasno sprecyzowane oczekiwania społeczne w stosunku do przedsiębiorstw. Dotyczą one nie tylko bezpieczeństwa proponowanych przez nie produktów, ale również uwzględniają stosowanie odpowiedzialnych praktyk, międzynarodowych standardów jakości czy deklarację stosowania ekologicznych i etycznych metod produkcji oraz ich dotrzymanie. Wybieranie produktów spełniających te kryteria jest przejawem zrównoważonych zachowań konsumpcyjnych, na które przedsiębiorstwa chcące utrzymać swoją pozycję rynkową muszą odpowiedzieć zrównoważoną produkcją.

\section{Zrównoważona produkcja i jej certyfikaty}

W literaturze pojawia się coraz więcej rozważań na temat zrównoważonego rozwoju (ang. sustainable development) definiowanego jako rozwój społeczno-gospodarczy, który zapewnia zaspokajanie potrzeb obecnego pokolenia bez zmniejszania szans zaspokajania potrzeb przyszłych pokoleń [WCED 1987]. Filarami zrównoważonego rozwoju są: wzrost gospodarczy, ochrona środowiska i odpowiedzialność społeczna, dzięki którym realizowane są jednocześnie cele ekonomiczne, społeczne oraz ekologiczne [Pilarczyk i Nestorowicz 2010, Nowacki 2014]. Elementem idei zrównoważonego rozwoju jest trwała i zrównoważona produkcja, definiowana jako „wykorzystanie towarów i usług, odpowiadające zaspokojeniu podstawowych potrzeb i prowadzące do lepszej jakości życia, przy jednoczesnej minimalizacji zużycia zasobów naturalnych i materiałów toksycznych oraz emisji odpadów i zanieczyszczeń, w całym cyklu życia produktu lub usługi, w taki sposób, aby nie zagrażać potrzebom przyszłych pokoleń oraz wspieranie konsumentów w dokonywaniu lepszych wyborów" [UNEP 2010].

W wyniku zrównoważonej produkcji, której podstawą jest respektowanie w stopniu większym niż przy produkcji konwencjonalnej wymogów ekologicz- 
nych i społecznych, powstają produkty opatrzone certyfikatami, których symbole (pełniące funkcję gwarancji) umieszczane są na opakowaniach. Znakowanie produktów umożliwia komunikację z konsumentem poprzez jednoznaczne poinformowanie go o metodzie produkcji i spełnionych standardach [Adamowicz i Jasiulewicz 2003, Żakowska-Biemans i Gutkowska 2003]. Dzięki temu współcześni konsumenci coraz częściej świadomie podejmują decyzje zakupowe, wykorzystując w tym celu informacje umieszczane na opakowaniach produktów [Śmiechowska 2012].

Wśród funkcjonujących znaków i certyfikatów zrównoważonej produkcji do celów badawczych wybrano sześć, które zostały przedstawione w tabeli 1 . Certyfikaty te były najczęściej wskazywane przez respondentów jako rozpoznawalne.

\section{Metodyka badań własnych}

Podstawą prezentowanych rozważań są wyniki badania przeprowadzonego w 2015 roku na kwotowej próbie 963 młodych konsumentów w wieku 19-35 lat (w większości studentów), zamieszkujących dziewięć dużych aglomeracji miejskich (Białystok, Trójmiasto, Katowice, Kraków, Poznań, Rzeszów, Szczecin, Warszawa, Wrocław), zróżnicowanych pod względem płci, wieku oraz poziomu miesięcznego dochodu netto gospodarstwa domowego per capita. Rozkład badanej próby respondentów przedstawia tabela 2 .

W badaniu zastosowano metodę sondażu diagnostycznego. Pomiary prowadzono z użyciem autorskiego kwestionariusza, zawierającego pytania poruszające między innymi problematykę wiedzy i zainteresowania młodych konsumentów CSR, pozwalające określić poziom ich zaufania wobec takich działan, a także znajomość znaków symbolizujących respektowanie zasad zrównoważonej produkcji artykułów żywnościowych i zaufanie wobec nich [Wasilik 2017]. Dla potrzeb realizacji celu artykułu skoncentrowano się na dwóch problemach badawczych:

1) Jaki jest i od czego zależy poziom znajomości certyfikatów zrównoważonej produkcji?

2) Jaki jest i od czego zależy poziom zaufania wobec certyfikatów zrównoważonej produkcji?

W analizie wykorzystano istotne statystycznie wskaźniki struktury (odsetki) oraz miary korelacji między zmiennymi. Zależności między zmiennymi niezależnymi (objaśniającymi) a zależnymi (objaśnianymi) określono na podstawie testu nieparametrycznego $\chi^{2}$, a siłę zidentyfikowanych zależności wyznaczono przy użyciu współczynnika V-Cramera. 
Tabela 1

Logo i certyfikaty zrównoważonej produkcji

\begin{tabular}{|c|c|}
\hline Logo & Charakterystyka certyfikatu \\
\hline 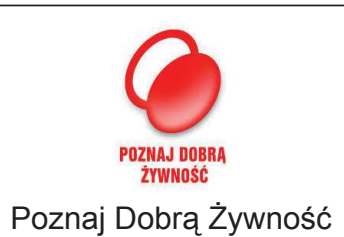 & $\begin{array}{l}\text { Znak jakości mający na celu informowanie konsumenta o wyso- } \\
\text { kiej jakości produktów żywnościowych, zarówno pod względem } \\
\text { surowców, jak i warunków produkcji. Program jest narzędziem } \\
\text { służącym do realizowanie polityki UE w zakresie żywności, po- } \\
\text { legającej na poszerzaniu obszaru wysokiej jakości i różnorod- } \\
\text { ności żywności na wewnętrznym rynku UE. }\end{array}$ \\
\hline & $\begin{array}{l}\text { Aktualnie obowiazujący znak certyfikacyjny rolnictwa ekolo- } \\
\text { gicznego, potwierdzający spełnienie wymagań rozporządzenia } \\
\text { UE, działający na terytorium państw członkowskich, będący dla } \\
\text { konsumenta gwarancja ekologicznego pochodzenia i wysokiej } \\
\text { jakości produktów. }\end{array}$ \\
\hline giczne & $\begin{array}{l}\text { Wprowadzony pod koniec lat } 90 \text {. XX wieku certyfikat rolnictwa } \\
\text { ekologicznego mającego na celu wytwarzanie zdrowych i wyso- } \\
\text { kiej jakości produktów żywności z zastosowaniem środków na- } \\
\text { turalnych, a także dbałość o żyzność gleb, dobrostan zwierząt } \\
\text { i ochronę środowiska podczas produkcji rolniczej. }\end{array}$ \\
\hline $\begin{array}{l}\text { FAIRT } \\
\text { Fairtrade In }\end{array}$ & $\begin{array}{l}\text { Certyfikat gwarantujący wytwarzanie z zachowaniem zasad } \\
\text { Fairtrade, obejmujących godne wynagradzanie zatrudnionych, } \\
\text { przestrzeganie praw pracowniczych, wypłacanie premii roz- } \\
\text { wojowych dla lokalnych społeczności, udział w podejmowaniu } \\
\text { decyzji, eliminowanie wpływu pośredników nadużywających } \\
\text { pozycji przetargowej oraz dążenie do wzrostu niezależności } \\
\text { producentów i zrównoważonego rozwoju. }\end{array}$ \\
\hline Rainforest Alliance & $\begin{array}{l}\text { Certyfikat przyznawany produktom, których proces powstawa- } \\
\text { nia nie wpływa negatywnie na miejscowe lasy, gleby, rzeki czy } \\
\text { zwierzęta. Ma na celu ochronę lasów deszczowych i bioróżno- } \\
\text { rodności. Przyznawany jest różnym grupom produktów oraz } \\
\text { hodowli bydła i farmom przyjaznym klimatowi i zrównoważonej } \\
\text { turystyce. }\end{array}$ \\
\hline & $\begin{array}{l}\text { Certyfikat gwarantujący wytwarzanie produktów w sposób od- } \\
\text { powiedzialny, z poszanowaniem ludzi zaangażowanych w pro- } \\
\text { dukcję, poprzez zapewnienie im odpowiednich warunków pracy } \\
\text { oraz z uwzględnieniem aspektu środowiska poprzez optymali- } \\
\text { zację zużycia wody, wycinki drzew i ochronę zagrożonych ga- } \\
\text { tunków. }\end{array}$ \\
\hline
\end{tabular}

Źródło: Opracowanie własne na podstawie: MRiRW http://www.minrol.gov.pl/Jakosc-zywnosci/Poznaj-Dobra-Zywnosc (dostęp: 10.07.2017), KE, https://ec.europa.eu/agriculture/organic/organic-farming_pl (dostęp: 10.07.2017), http://www.fairtrade.net, http://www.rainforestalliance.org (dostęp: 10.07.2014), https://utz.org (dostęp: 10.07.2017). 
Tabela 2

Charakterystyka badanej populacji

\begin{tabular}{|c|c|c|c|}
\hline \multicolumn{2}{|c|}{ Wyszczególnienie } & Liczba badanych & Procent badanych \\
\hline \multicolumn{2}{|c|}{ Ogółem } & 963 & 100,0 \\
\hline \multirow{2}{*}{ Płeć } & kobiety & 638 & 66,3 \\
\hline & mężczyźni & 325 & 33,7 \\
\hline \multirow{2}{*}{ Wiek [lata] } & 19-24 & 818 & 84,9 \\
\hline & $25-35$ & 145 & 15,1 \\
\hline \multirow{6}{*}{$\begin{array}{l}\text { Miesięczny } \\
\text { dochód netto } \\
\text { gospodarstwa } \\
\text { domowego } \\
\text { [zł per capita] }\end{array}$} & $\leq 700$ & 143 & 14,8 \\
\hline & $700-1000$ & 159 & 16,5 \\
\hline & $1001-1500$ & 204 & 21,2 \\
\hline & $1501-2000$ & 139 & 14,4 \\
\hline & $2001-3000$ & 144 & 15,0 \\
\hline & $\geq 3000$ & 174 & 18,1 \\
\hline
\end{tabular}

Źródło: Badanie własne (2015).

Wyniki analiz zostały zaprezentowane z uwzględnieniem zróżnicowania na dwie podstawowe kategorie demograficzne pokazujące największe zróżnicowanie postaw (płeć i wiek z rozbiciem na dwie grupy: młodszą z osobami w wieku 19-24 lata i starszą z osobami w wieku 25-35 lat), poziom zamożności mierzony wielkością miesięcznych dochodów netto w gospodarstwie domowym na osobę, a także zmienną określającą stosunek do CSR wyrażony trzema kategoriami: zainteresowanie działaniami CSR, brak takich zainteresowań i nieznajomość problematyki CSR.

\section{Wyniki badania własnego}

Z przeprowadzonego badania wynika, że młodzi konsumenci w Polsce w niewielkim stopniu interesują się działaniami związanymi z CSR przedsiębiorstw, których produkty kupują. Jedynie $21,9 \%$ uczestników przyznało, że śledzi tego typu działania tylko znanych sobie firm. Prawie $60 \%$ badanych nie interesowało się tą problematyka, a co piąty o takich działaniach nigdy nie słyszał (tab. 3).

Odpowiedzi nie były istotnie zróżnicowane pod względem płci i wieku respondentów. W nieco większym stopniu uwidoczniły się różnice między poszczególnymi grupami dochodowymi. Nieznaczna przewaga twierdzących odpowiedzi odnotowana została wśród kobiet (22,3\%), młodszej grupiej wiekowej $(22,0 \%)$ oraz wśród osób najbardziej zamożnych $(25,9 \%)$. Wspomniane zależności między zainteresowaniem działalnością związaną z CSR 
Tabela 3

Zainteresowanie działaniami związanymi ze społeczną odpowiedzialnością przedsiębiorstw $(\mathrm{N}=963)$

\begin{tabular}{|c|c|c|c|c|}
\hline \multirow{2}{*}{\multicolumn{2}{|c|}{ Wyszczególnienie }} & $\begin{array}{c}\text { Tak, jestem } \\
\text { zainteresowany/a }\end{array}$ & $\begin{array}{l}\text { Nie, nie jestem } \\
\text { zainteresowany/a }\end{array}$ & $\begin{array}{c}\text { Nie słyszałem/am } \\
\text { o takich } \\
\text { działaniach }\end{array}$ \\
\hline & & \multicolumn{3}{|c|}{ procent wskazań } \\
\hline \multicolumn{2}{|c|}{ Ogółem } & 21,9 & 59,7 & 18,4 \\
\hline \multirow{2}{*}{ Płeć } & kobiety & 22,3 & 60,0 & 17,7 \\
\hline & mężczyźni & 21,2 & 59,1 & 19,7 \\
\hline \multirow{2}{*}{ Wiek [lata] } & $19-24$ & 22,0 & 59,5 & 18,5 \\
\hline & $25-35$ & 21,4 & 60,7 & 17,9 \\
\hline \multirow{6}{*}{$\begin{array}{l}\text { Dochód netto } \\
\text { na osobę } \\
\text { w gospodar- } \\
\text { stwie domo- } \\
\text { wym [zł] }\end{array}$} & $\leq 700$ & 19,6 & 52,4 & 28,0 \\
\hline & 700-1000 & 23,3 & 56,6 & 20,1 \\
\hline & $1001-1500$ & 20,6 & 63,2 & 16,2 \\
\hline & $1501-2000$ & 18,0 & 63,3 & 18,7 \\
\hline & $2001-3000$ & 23,6 & 63,9 & 12,5 \\
\hline & $\geq 3000$ & 25,9 & 58,0 & 16,1 \\
\hline
\end{tabular}

Źródło: Badanie własne (2015).

a cechami respondentów nie są jednak istotne ze statystycznego punktu widzenia. W żadnej zmiennej opisującej respondentów nie zidentyfikowano zależności przy $\alpha=0,05$.

$\mathrm{Na}$ tle zainteresowania CSR zbadano znajomość umieszczanych na produktach certyfikatów charakteryzujących zrównoważoną produkcję, a także zaufanie wobec tych znaków. Największą rozpoznawalnością cieszyło się logo Poznaj Dobrą Żywność (tab. 4). Jego znajomość zadeklarowało 62,4\% respondentów. Częściej było ono znane kobietom, osobom w wieku 19-24 lata i pochodzącym z średnio zamożnych gospodarstw domowych oraz zarówno zainteresowanym działalnością CSR, jak i niemającym wiedzy na ten temat. Nieznacznie rzadziej deklarowano znajomość znaków Rolnictwa Ekologicznego oraz Fairtrade (po $59,7 \%$ wskazań). Ich znajomość również częściej deklarowały kobiety i osoby w wieku 19-24 lata. Biorąc pod uwagę dochody respondentów, rozpoznawalność Rolnictwa Ekologicznego była większa wśród osób o najniższym ich poziomie, a w przypadku Fairtrade wśród najbardziej zamożnych. Oba znaki były znacznie lepiej rozpoznawalne wśród osób zainteresowanych działaniami CSR niż wśród respondentów nieprzejawiających takiego zainteresowania lub nieposiadających wiedzy na temat społecznej odpowiedzialności. Znaki Euro-liścia oraz Rainforest Alliance były kojarzone przez nieco ponad $40 \%$ badanych. Zdecydowanie najmniejszą rozpoznawalnością charakteryzował się natomiast symbol UTZ - 
rozpoznało go jedynie $17,4 \%$ badanych. Wyraźnie można dostrzec większą znajomość tych trzech ostatnich symboli wśród osób deklarujących zainteresowanie działaniami CSR (różnica w stosunku do pozostałych respondentów sięgająca 20 p.p.).

Tabela 4

Znajomość certyfikatów zrównoważonej produkcji wśród respondentów ( $\mathrm{N}=963)$

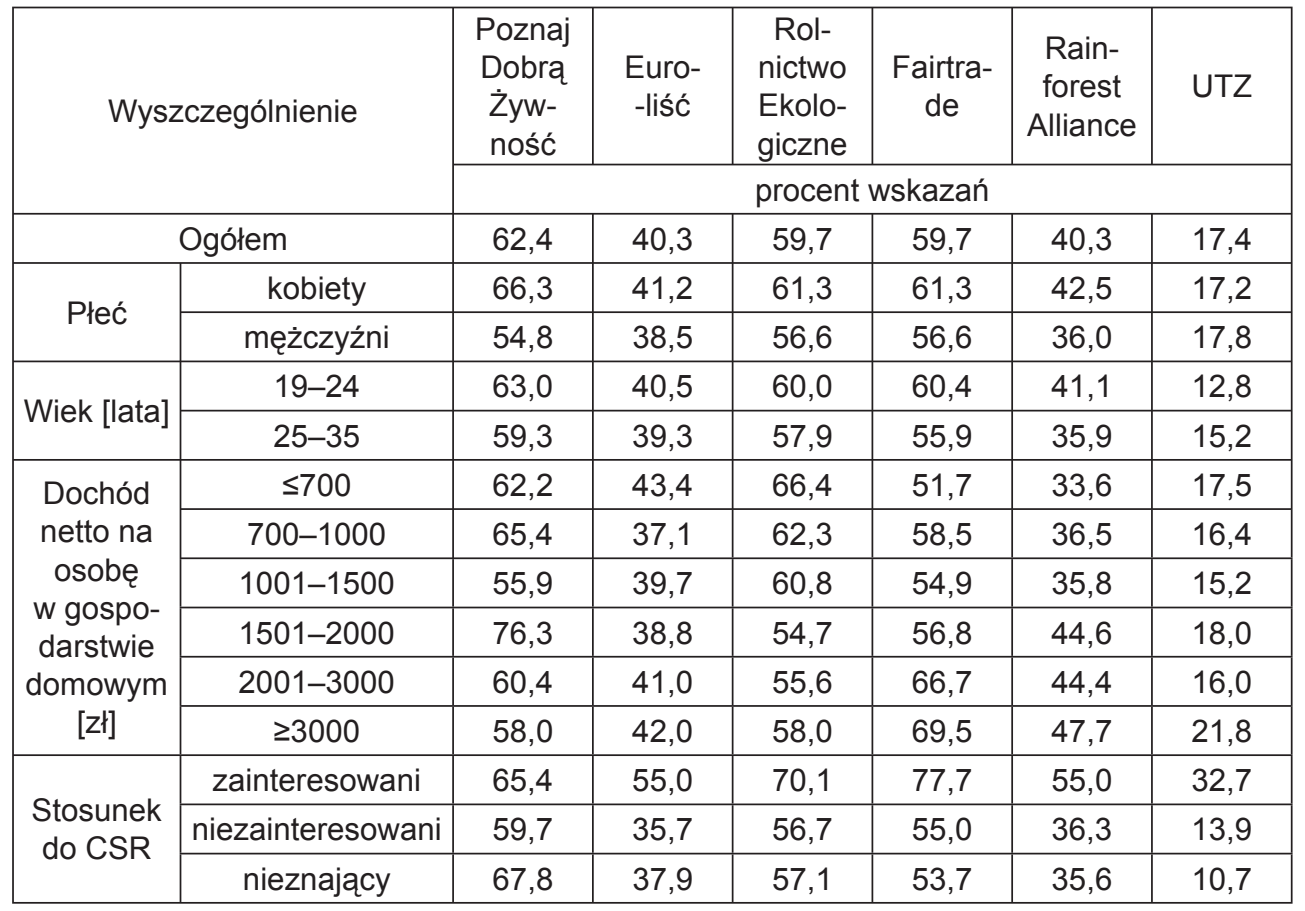

Źródło: Badanie własne (2015).

Wskazane różnice są tylko w części istotne statystycznie. Spośród 24 możliwych zależności (sześć znaków razy cztery zmienne objaśniające) analiza z wykorzystaniem testu $\chi^{2}$ wykazała istnienie statystycznie istotnej zależności na poziomie $\alpha=0,05$ jedynie w dziewięciu przypadkach (tab. 5).

Cechą w największym stopniu wpływającą na znajomość certyfikatów jest stosunek do działań CSR. Statystycznie istotna współzależność między tą zmienną a rozpoznawalnością znaków wystąpiła w przypadku pięciu certyfikatów (Euro-liść, Rolnictwo Ekologiczne, Fairtrade, Rainforest Alliance i UTZ). W przypadku trzech znaków (Poznaj Dobrą Żywność, Fairtrade i Rainforest Alliance) korelacja dotyczyła miesięcznego dochodu netto gospodarstwa domowego per capita, a w jednym (Poznaj Dobrą Żywność) również płci. Nie stwierdzono natomiast żadnej zależności istotnej statystycznie między znajomością certy- 
Tabela 5

Ocena zależności między znajomością certyfikatów zrównoważonej produkcji a zmiennymi opisującymi respondentów

\begin{tabular}{|c|c|c|c|c|c|}
\hline Wyszczególnienie & $x^{2}$ & df & $\begin{array}{c}\text { Istotność } \\
\text { asymptotyczna } \\
\text { (dwustronna) }\end{array}$ & $\begin{array}{c}\text { Współczyn- } \\
\text { nik } \\
\text { V-Cramera }\end{array}$ & $\begin{array}{c}\text { Decyzja } \\
\text { o zależności } \\
\text { przy } \\
\alpha=0,05\end{array}$ \\
\hline \multicolumn{6}{|c|}{ Poznaj Dobrą Żywność } \\
\hline Płeć & 12,205 & 1 & 0,000 & 0,113 & istotna, słaba \\
\hline Wiek & 0,699 & 1 & 0,403 & 0,027 & nieistotna \\
\hline Dochód & 17,337 & 5 & 0,004 & 0,134 & istotna, słaba \\
\hline Stosunek do CSR & 4,859 & 2 & 0,088 & 0,071 & nieistotna \\
\hline \multicolumn{6}{|c|}{ Euro-liść } \\
\hline Płeć & 0,682 & 1 & 0,409 & 0,027 & nieistotna \\
\hline Wiek & 0,068 & 1 & 0,794 & 0,008 & nieistotna \\
\hline Dochód & 1,606 & 5 & 0,901 & 0,041 & nieistotna \\
\hline Stosunek do CSR & 24,495 & 2 & 0,000 & 0,159 & istotna, słaba \\
\hline \multicolumn{6}{|c|}{ Rolnictwo Ekologiczne } \\
\hline Płeć & 1,952 & 1 & 0,162 & 0,045 & nieistotna \\
\hline Wiek & 0,224 & 1 & 0,636 & 0,015 & nieistotna \\
\hline Dochód & 5,914 & 5 & 0,315 & 0,078 & nieistotna \\
\hline Stosunek do CSR & 12,233 & 2 & 0,002 & 0,113 & istotna, słaba \\
\hline \multicolumn{6}{|c|}{ Fairtrade } \\
\hline Płeć & 1,952 & 1 & 0,162 & 0,045 & nieistotna \\
\hline Wiek & 1,050 & 1 & 0,305 & 0,033 & nieistotna \\
\hline Dochód & 16,190 & 5 & 0,006 & 0,130 & istotna, słaba \\
\hline Stosunek do CSR & 36,548 & 2 & 0,000 & 0,195 & istotna, słaba \\
\hline \multicolumn{6}{|c|}{ Rainforest Alliance } \\
\hline Płeć & 3,754 & 1 & 0,053 & 0,062 & nieistotna \\
\hline Wiek & 1,392 & 1 & 0238 & 0,038 & nieistotna \\
\hline Dochód & 11,450 & 5 & 0,043 & 0,109 & istotna, słaba \\
\hline Stosunek do CSR & 24,255 & 2 & 0,000 & 0,159 & istotna, słaba \\
\hline \multicolumn{6}{|c|}{ UTZ } \\
\hline Płeć & 0,055 & 1 & 0,815 & 0,008 & nieistotna \\
\hline Wiek & 0,612 & 1 & 0,434 & 0,025 & nieistotna \\
\hline Dochód & 3,426 & 5 & 0,635 & 0,060 & nieistotna \\
\hline Stosunek do CSR & 44,616 & 2 & 0,000 & 0,215 & istotna, słaba \\
\hline
\end{tabular}

Źródło: Badanie własne (2015). 


\section{4}

fikatów a wiekiem badanych. We wszystkich wykazanych zależnościach ich siła jest jednak niewielka. Współczynniki V-Cramera pokazujące siłę tych zależności wahają się w granicach od 0,109 do 0,215 - osiągając maksymalną wartość dla związku między znajomością certyfikatu UTZ a stosunkiem do CSR.

Nieco inaczej przedstawiały się deklaracje zaufania do analizowanych certyfikatów (tab. 6). Największy odsetek respondentów (42,1\%) wskazał certyfikat Fairtrade. Trzech na dziesięciu respondentów oświadczyło, że ufa znakom Rolnictwa Ekologicznego i Poznaj Dobrą Żywność. Wyraźnie rzadsze wskazania uzyskały certyfikaty Rainforest Alliance oraz Euro-liść (odpowiednio 17,8 oraz 13,9\%), a przede wszystkim UTZ (tylko 6,2\%). Zaufanie do symboli generalnie nieco częściej (poza UTZ) deklarowały kobiety i osoby między 25. a 35. rokiem życia. Osoby o najniższych dochodach obdarzyły większym zaufaniem certyfikaty Poznaj Dobrą Żywność, Rolnictwo Ekologiczne oraz Euro-liść, a o najwyższych dochodach pozostałe znaki. Osoby aktywnie śledzące działalność CSR były generalnie znacznie bardziej skłonne do obdarzania zaufaniem wszystkich badanych certyfikatów.

Analiza zależności między zaufaniem wobec nich a cechami opisującymi respondentów pokazała, że stosunek do CSR ma duży wpływ na zaufanie wobec

Tabela 6

Zaufanie wobec certyfikatów zrównoważonej produkcji wśród respondentów (N = 963)

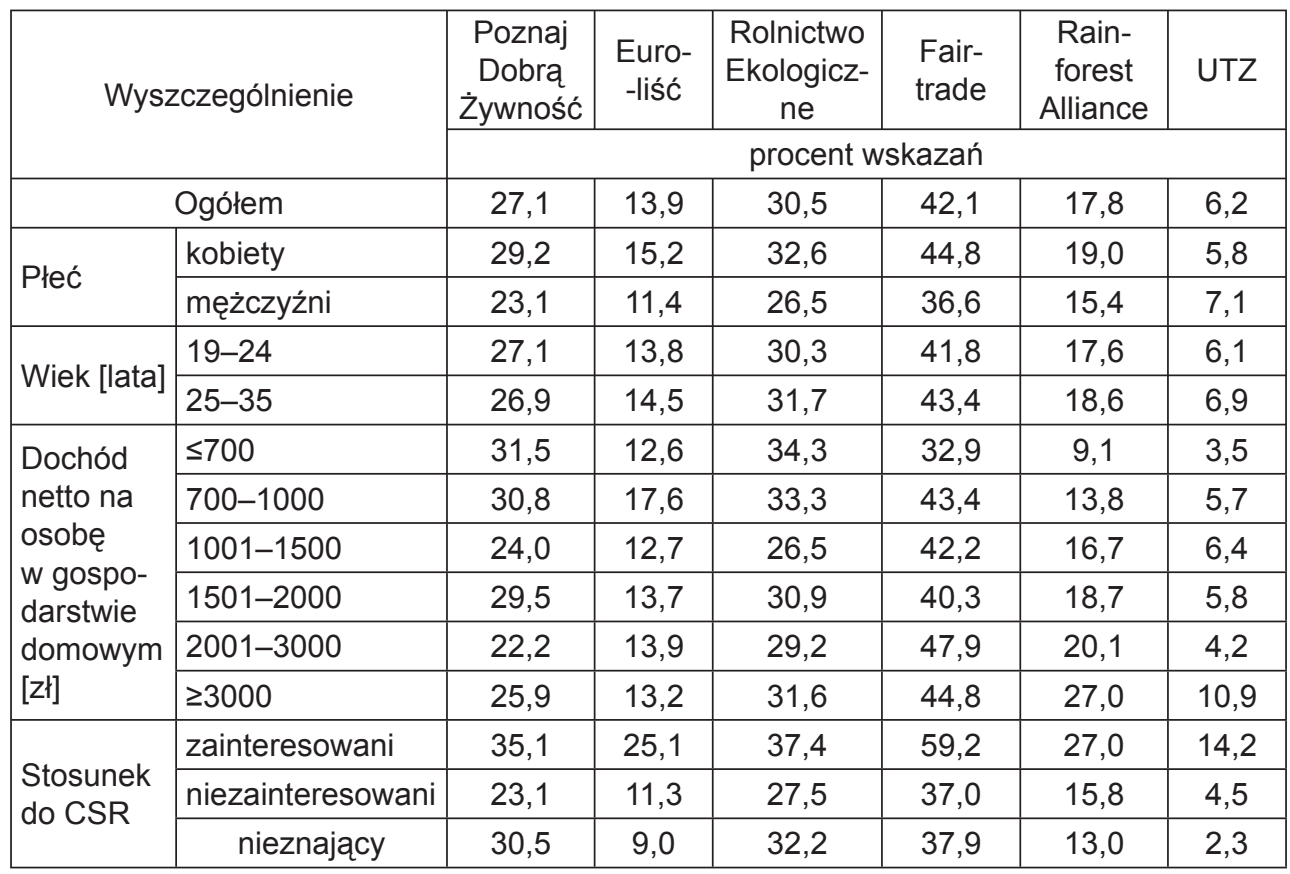

Źródło: Badanie własne (2015). 
certyfikatów zrównoważonej produkcji (tab. 7). W przypadku wszystkich sześciu znaków stwierdzono statystycznie istotną zależność - osoby zainteresowane takimi działaniami wykazywały się wyższym poziomem zaufania, choć określona przy użyciu współczynnika V-Cramera siła zależności była mała (maksymalnie 0,185 w przypadku certyfikatu Fairtrade). W przypadku trzech znaków (Poznaj Dobrą Żywność, Rolnictwo Ekologiczne i Fairtrade) zależność wystapiła w odniesieniu do cechy płeć respondenta, ale jej siła była jeszcze mniejsza (nie przekroczyła wartości 0,079). Dochód determinował zaufanie jedynie wobec znaku Rainforest Alliance (siła zależności wynosząca 0,144 ). Nie wystapiły natomiast zależności między zaufaniem do certyfikatów a wiekiem badanych.

\section{Tabela 7}

Ocena zależności między zaufaniem wobec certyfikatów zrównoważonej produkcji a zmiennymi opisującymi respondentów

\begin{tabular}{|c|c|c|c|c|c|}
\hline Wyszczególnienie & $x^{2}$ & $d f$ & $\begin{array}{c}\text { Istotność } \\
\text { asymptotyczna } \\
\text { (dwustronna) }\end{array}$ & $\begin{array}{c}\text { Współczyn- } \\
\text { nik } \\
\text { V-Cramera }\end{array}$ & $\begin{array}{c}\text { Decyzja } \\
\text { o zależności } \\
\text { przy } \\
\alpha=0,05\end{array}$ \\
\hline 1 & 2 & 3 & 4 & 5 & 6 \\
\hline \multicolumn{6}{|c|}{ Poznaj Dobrą Żywność } \\
\hline Płeć & 4,024 & 1 & 0,045 & 0,065 & istotna, słaba \\
\hline Wiek & 0,004 & 1 & 0,952 & 0,002 & nieistotna \\
\hline Dochód & 5,746 & 5 & 0,332 & 0,077 & nieistotna \\
\hline Stosunek do CSR & 12,412 & 2 & 0,002 & 0,114 & istotna, słaba \\
\hline \multicolumn{6}{|c|}{ Euro-liść } \\
\hline Płeć & 2,622 & 1 & 0,105 & 0,052 & nieistotna \\
\hline Wiek & 0,046 & 1 & 0,830 & 0,007 & nieistotna \\
\hline Dochód & 2,333 & 5 & 0,801 & 0,049 & nieistotna \\
\hline Stosunek do CSR & 28,894 & 2 & 0,000 & 0,173 & istotna, słaba \\
\hline \multicolumn{6}{|c|}{ Rolnictwo Ekologiczne } \\
\hline Płeć & 3,828 & 1 & 0,050 & 0,063 & istotna, słaba \\
\hline Wiek & 0,115 & 1 & 0,735 & 0,011 & nieistotna \\
\hline Dochód & 4,206 & 5 & 0,520 & 0,066 & nieistotna \\
\hline Stosunek do CSR & 7,510 & 2 & 0,023 & 0,088 & istotna, słaba \\
\hline \multicolumn{6}{|c|}{ Fairtrade } \\
\hline Płeć & 5,959 & 1 & 0,015 & 0,079 & istotna, słaba \\
\hline Wiek & 0,136 & 1 & 0,713 & 0,012 & nieistotna \\
\hline Dochód & 7,829 & 5 & 0,166 & 0,090 & nieistotna \\
\hline
\end{tabular}


Tabela $7 \mathrm{~cd}$.

\begin{tabular}{|l|c|c|c|c|c|}
\hline \multicolumn{1}{|c|}{1} & 2 & 3 & 4 & 5 & 6 \\
\hline Stosunek do CSR & 32,784 & 2 & 0,000 & 0,185 & istotna, słaba \\
\hline \multicolumn{5}{|c|}{ Rainforest Alliance } \\
\hline Płeć & 1,891 & 1 & 0,169 & 0,044 & nieistotna \\
\hline Wiek & 0,087 & 1 & 0,768 & 0,010 & nieistotna \\
\hline Dochód & 20,043 & 5 & 0,001 & 0,144 & istotna, słaba \\
\hline Stosunek do CSR & 16,599 & 2 & 0,000 & 0,131 & istotna, słaba \\
\hline \multicolumn{5}{|c|}{ UTZ } \\
\hline Płeć & 0,602 & 1 & 0,438 & 0,025 & nieistotna \\
\hline Wiek & 0,130 & 1 & 0,719 & 0,012 & nieistotna \\
\hline Dochód & 9,577 & 5 & 0,088 & 0,100 & nieistotna \\
\hline Stosunek do CSR & 30,692 & 2 & 0,000 & 0,179 & istotna, słaba \\
\hline
\end{tabular}

Źródło: Badanie własne (2015).

\section{Podsumowanie}

Przedstawione wyniki pokazują relatywnie niski poziom świadomości młodych konsumentów odnośnie społecznej odpowiedzialności przedsiębiorstw. Jest to zasadniczo zbieżne z rezultatami innych badań prowadzonych w społeczeństwie polskim. Z badań dokonanych w ramach projektu „Barometr CSR” w 2016 roku wynika, że tylko $38 \%$ Polaków posiada znaczną wiedzę w tym zakresie i wyraża gotowość jej wykorzystywania w zachowaniach rynkowych, wybierając produkty przedsiębiorstw społecznie zaangażowanych i rekomendując je innym [Greszta i Maison 2016]. Z kolei badania w ramach projektu „CSR w praktyce" realizowane w 2017 roku wskazują, że tylko 35\% respondentów dostrzega działania z CSR i łączy to z większym zaufaniem wobec tak zachowujących się przedsiębiorstw [CSR $w$ praktyce..., 2017].

Małe wartości wskaźników zainteresowania taką aktywnością wśród młodych konsumentów z pewnością nie są satysfakcjonujące. Przekłada się to na rozpoznawalność i postrzeganie konkretnych działań związanych ze społeczną odpowiedzialnością. Poziom znajomości certyfikatów charakteryzujacych zrównoważoną produkcję również jest relatywnie wysoki (ponad połowa młodych konsumentów identyfikuje znaki Poznaj Dobrą Żywność, Fairtrade oraz Rolnictwo Ekologiczne, a dalsze 40\% z nich zna również symbole Euro-liścia i Rainforest Alliance), ale odsetek wyrażających zaufanie wobec tych znaków jest znacznie niższy - poza Fairtrade sięga co najwyżej 30\%.

Wyraźnie widać przy tym, że deklarowane zainteresowanie społeczną odpowiedzialnością dodatnio wpływa na znajomość i poziom zaufania wobec cer- 
tyfikatów potwierdzających zaangażowanie przedsiębiorstw. Znacznie mniejszy wpływ mają cechy demograficzne respondentów (przede wszystkim płeć) oraz ekonomiczne (poziom zamożności gospodarstwa domowego).

Wynika z tego potrzeba prowadzenia działań edukacyjnych wśród młodych konsumentów - konieczność zaznajamiania ich z koncepcją społecznej odpowiedzialności i jej praktycznymi implikacjami, a także konieczność zwiększenia wiarygodności takich działań. Otwiera to dalsze możliwości badawcze. W takim kontekście należałoby rozwijać projekty diagnozujące przyczyny małego zaufania wobec CSR w celu wypracowania odpowiednich modeli komunikacji z konsumentami mogących zwiększyć nie tylko poziom świadomości, ale i zaufanie wobec tego typu inicjatyw.

\section{Literatura}

ADAMOWICZ M., JASIULEWICZ A., 2003: Znakowanie produktów spożywczych jako instrument marketingu i zapewnienia bezpieczeństwa żywnościowego, Wydawnictwo SGGW, Warszawa.

BERGH J., van den BEHRER M., 2012: Jak kreować marki, które pokocha pokolenie Y?, Edgard, Warszawa.

BUCHHOLZ R.A., 1991: Corporate Responsibility and the Good Society: From Economics to Ecology, Business Horizons 34(4), 19-31.

CARROLL A.B., 1991: The Pyramid of Corporate Social Responsibility: Towards the Moral Management of Organizational Stakeholders, Business Horizons 34(4), 39-48.

CHAHAL H., SHARMA R.D., 2012: Implications of Corporate Social Responsibility on Marketing Performance: A Conceptual Framework, Journal of Services Research 6(1), 205-216.

Commission of the European Communities (CEC), 2001: Green Paper. Promoting a European Framework for Corporate Social Responsibility, Brussels.

CZUBAŁA A., 2011: Rola konsumentów w realizacji spolecznej odpowiedzialności przedsiębiorstw, Konsumpcja i Rozwój 1(1), 58-66.

CSR w praktyce - barometr Francusko-Polskiej Izby Gospodarczej, 2017, www.http://odpowiedzialnybiznes.pl/wp-content/uploads/2017/06/CCIFP_broszura_CRS_2017_pl_ v06.pdf (dostęp: 10.07.2017).

DRAPIŃSKA A., 2015: Marketing a spoleczna odpowiedzialność biznesu-sprzeczne idee?, Zeszyty Naukowe Uniwersytetu Szczecińskiego, Problemy Zarządzania, Finansów i Marketingu 785(41), 1, 277-287.

Economist Intelligence Unit, 2009: Management Magnified Sustainability and Corporate Growth, London, http:graphics.eiu.com/upload/eb/SAS_Sustainability_WEB.pdf (dostęp: 05.07.2014).

FREEMAN R.E., 1984: Strategic Management: A Stakeholder Approach, Pitman Publishing, Boston. 
FREEMAN R.E., EVAN W.M., 1990: Corporate Governance: A Stakeholder Interpretation, Journal of Behavioral Economics 19(4), 337-359.

GRESZTA M., MAISON D., 2016: Konsument w Polsce wobec działań CSR, http://www. marketing-news.pl/message.php?art=47467 (dostęp: 10.07.2017).

GRISERI P., SEPPALA N., 2010: Business Ethics and Corporate Social Responsibility, South-Western Cengage Learning, Lincoln.

HUMPHERY K., 2011: The Simple and the Good: Ethical Consumption as Anti-consumerism, [w:] T. Lewis, E. Potter (red.), Ethical Consumption - A Critical Introduction, Routledge, London - New York, 40-53.

LEVITT T., 1958: The Dangers of Social Responsibility, Harvard Business Review 36(5), $41-50$.

LUO X., BHATTACHARYA C.B., 2006: Corporate Social Responsibility, Customer Satisfaction, and Market Value, Journal of Marketing 70(4), 1-18.

NOWACKI R., 2014: Ekologiczne motywy w reklamie a idea zrównoważonej konsumpcji, Konsumpcja i Rozwój 4(9), 24-39.

NOWACKI R., WASILIK K., 2017: Towards Responsible Consumption-Attitudes of Young Consumers to the Idea of Corporate Social Responsibility, Handel Wewnętrzny 63(2), 280-293.

OMG! Czyli jak mówić do polskich milenialsów, 2014, Odyseja Public Relations, Warszawa.

PILARCZYK B., NESTOROWICZ R., 2010: Marketing ekologicznych produktów żywnościowych, Wolters Kluwer Polska, Warszawa.

SŁABY T., 1990: Poziom życia, jakość życia, Wiadomości Statystyczne 6.

ŚMIECHOWSKA M., 2012: Znakowanie produktów żywnościowych, Annales Academiae Medicae Gedanensis 42, 65-73.

United Nations Environment Programme (UNEP) 2010: ABC of SCP, Clarifying Concepts on Sustainable Consumption and Production, https://sustainabledevelopment.un.org/ content/documents/945ABC_ENGLISH.pdf (dostęp: 14.08.2017).

WASILIK K., 2017: Zachowania młodych konsumentów na rynku produktów Sprawiedliwego Handlu, IBRKK, Warszawa.

WITEK L., 2011: Warunki skutecznych programów marketingowych zaangażowanych spotecznie i ekologicznie, Handel Wewnętrzny 2(2), 352-358.

WILBURN K., WILBURN R., 2014: The Double Bottom Line: Profit and Social Benefit, Business Horizons 57(1), 11-20.

World Bank, 2005: What Does Business Think about Corporate Social Responsibility?, Washington, DC.

World Commission on Environment and Development (WCED), 1987: Our Common Future, United Nations.

ZIELIŃSKA A., 2014: Zachowania konsumentów wobec społecznie odpowiedzialnych i nieodpowiedzialnych działań przedsiębiorstwa, Marketing i Rynek 11 (CD), 500-506.

ŻAKOWSKA-BIEMANS S., GUTKOWSKA K., 2003: Postawy konsumentów wobec żywności ekologicznej, [w:] M. Adamowicz (red.), Marketing w strategiach rozwoju sektora rolno-spożywczego, Wydawnictwo SGGW, Warszawa. 


\begin{abstract}
Abstrakt
Funkcjonowanie w warunkach zrównoważonego rozwoju wymaga od przedsiębiorstw uwzględniania nie tylko własnych interesów ekonomicznych, ale też zwracania uwagi na kwestie ogólnogospodarcze i społeczne, w tym dotyczące zrównoważonej konsumpcji. Celem artykułu jest analiza zależności między deklarowaną znajomością i zainteresowaniem działaniami z zakresu społecznej odpowiedzialności przedsiębiorstw (CSR) wśród młodych konsumentów a znajomością i zaufaniem wobec znaków, a także certyfikatów potwierdzających zrównoważoną produkcję. Podstawą rozważań są wyniki badania ilościowego prowadzonego na ogólnopolskiej próbie konsumentów w wieku 19-35 lat. Uzyskane wyniki badania pozwalają stwierdzić, że znajomość idei CSR w znacznie większym stopniu determinuje znajomość certyfikatów i zaufanie wobec nich niż cechy demograficzno-ekonomiczne młodych konsumentów.
\end{abstract}

Słowa kluczowe: społeczna odpowiedzialność przedsiębiorstw, zrównoważona produkcja i konsumpcja, młodzi konsumenci

\title{
Knowledge and confidence in sustainable production certificates and the idea of corporate social responsibility from the point of view of young consumers
}

\begin{abstract}
Functioning under the conditions of sustainable development requires companies to take into account not only their own economic interests but also to pay attention to general economic and social issues, including sustainable consumption. The aim of the article is to analyze the relationship between the declared awareness and interest in corporate social responsibility (CSR) activities among young consumers and the familiarity with and trust in the certificates confirming adherence to sustainable production principles. The results of quantitative research conducted on a sample of consumers aged 19-35 form the basis for this discussion. The findings of the study indicate that the knowledge of the CSR concept is determined by the knowledge of the certificates and trust in them to a much greater degree than by the demographic and economic characteristics of young consumers.
\end{abstract}

Key words: corporate social responsibility, sustainable production and consumption, young consumers 